\title{
COPPER ALLOYS WITH IMPROVED PROPERTIES: STANDARD INGOT METALLURGY VS. POWDER METALLURGY
}

\author{
Milan T. Jovanović*, Višeslava Rajković, Ivana Cvijović-Alagić \\ Department of Materials Science, Vinča Institute of Nuclear Sciences, \\ University of Belgrade, 11001 Belgrade, Serbia
}

Received 14.08.2014

Accepted 04.09.2014

\begin{abstract}
Three copper-based alloys: two composites reinforced with $\mathrm{Al}_{2} \mathrm{O}_{3}$ particles and processed through powder metallurgy $(\mathrm{P} / \mathrm{M})$ route, i.e. by internal oxidation $(\mathrm{Cu}-2.5 \mathrm{Al}$ composite) and by mechanical alloying $\left(\mathrm{Cu}-4.7 \mathrm{Al}_{2} \mathrm{O}_{3}\right)$ and $\mathrm{Cu}-0.4 \mathrm{Cr}-0.08 \mathrm{Zr}$ alloy produced by ingot metallurgy (vacuum melting and casting) were the object of this investigation. Light microscope and scanning electron microscope (SEM) equipped with electron X-ray spectrometer (EDS) were used for microstructural characterization. Microhardness and electrical conductivity were also measured. Compared to composite materials, $\mathrm{Cu}-0.4 \mathrm{Cr}-0.08 \mathrm{Zr}$ alloy possesses highest electrical conductivity in the range from 20 to $800^{\circ} \mathrm{C}$, whereas the lowest conductivity shows composite $\mathrm{Cu}-2.5 \mathrm{Al}$ processed by internal oxidation. In spite to somewhat lower electrical conductivity (probably due to inadequate density), $\mathrm{Cu}-2.5 \mathrm{Al}$ composite exhibits thermal stability enabling its application at much higher temperatures than materials processed by mechanical alloying or by vacuum melting and casting.

Key words: Mechanical alloying, Internal oxidation, $\mathrm{Al}_{2} \mathrm{O}_{3}$ particles, Chromium-rich particles, Thermal stability

\section{Introduction}

Age hardened copper alloys such as $\mathrm{Cu}-\mathrm{Cr}, \mathrm{Cu}-\mathrm{Zr}$ and $\mathrm{Cu}-\mathrm{Cr}-\mathrm{Zr}$ obtain high strength and hardness through the precipitation of tiny coherent particles from a supersaturated copper matrix [1]. Due to their good mechanical properties and high electrical conductivity, these alloys in the last decade have attracted widespread attention for application in electrical/thermal conducting field such as electrodes for resistance welding, trolley wire of electric railway, and electrical brush.

In general, application of low alloyed copper-based alloys with high electrical conductivity may be regarded as follows:
\end{abstract}

*Corresponding author: Milan T. Jovanović, miljov@vin.bg.ac.rs 
- Different types of high electrical conductivity alloys have been developed. Most common are $\mathrm{Cu}-\mathrm{Cr}$ and $\mathrm{Cu}-\mathrm{Zr}$ alloys,

- small amounts of the third element additions are required to achieve optimum properties in these binary alloys,

- the chemical composition and especially technology of their processing are protected by patents or clasified documents.

The process of electrical-resistance welding reached full development in the production of aviation assemblies, car chassis and bodies, metallic furniture and other applications. This welding process uses pure copper (not advisable!) and copper-based alloys as the electrode material. Electrical-resistance spot welding involves passing a high current at a low voltage through a circuit closed by the pieces to be welded. The generated heat is sufficient to produce local fusion of the pieces under pressure, leading to an autogenously forged union. The drawing of of resistance spot welding is shown in Figure 1.

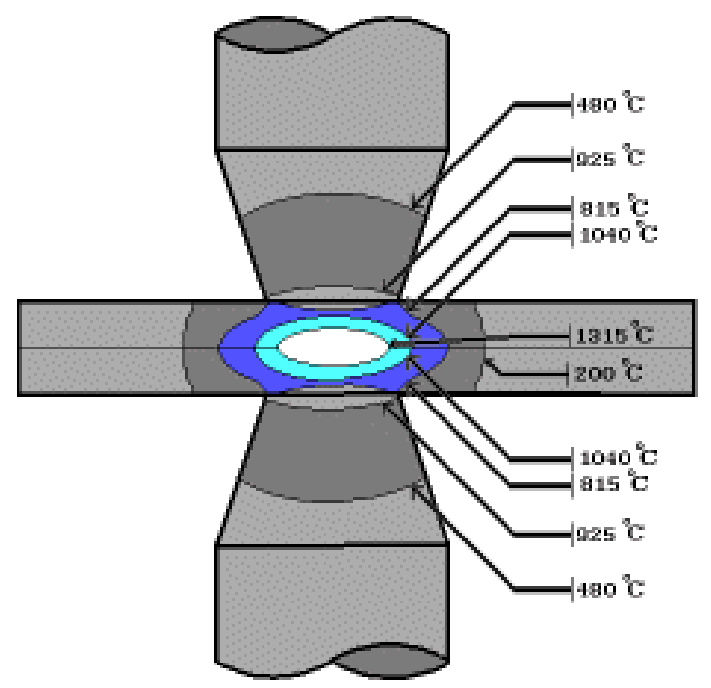

Figure 1 Set up of spot welded material inserted between a pair of electrodes with a span of temperatures developed during spot welding.

Thus, electrode materials must exhibit high electrical and thermal conductivities combined with high strength and low wear rate at elevated temperatures.

\section{What are disadvantages of these alloys}

Two deficiencies, characteristic for the precipitation hardened materials, which limit the further application of these alloys are:

- At elevated temperatures the precipitated phases may grow and dissolve again in the copper matrix, therefore the mechanical properties of these alloys are significantly reduced,

- lack of enough load bearing components on the surface and in the subsurface region results in the relatively low wear resistance of these alloys. 


\section{New copper-based alloys}

Particulate reinforced copper matrix composites have been regarded as new promising candidates of electrical and thermal conduction functional materials in the last few years. Previous works has proved that addition of hard particles such as $\mathrm{SiC}$, $\mathrm{Al}_{2} \mathrm{O}_{3}, \mathrm{TiB}_{2}$ and $\mathrm{TiC}$ [2-4] can significantly improve the mechanical properties of copper matrix materials while maintaining high electrical and thermal conductivity. The incorporation of ceramic particles as reinforcement may also enhance the hightemperature mechanical properties, oxidation and wear resistance, without severe deterioration of thermal and electrical conductivity of the copper matrix. On account of the low price, $\mathrm{Al}_{2} \mathrm{O}_{3}$ particles have been mostly selected as the reinforcement phase [57]. The uniform distribution of $\mathrm{Al}_{2} \mathrm{O}_{3}$ particles can be accomplished by the process of internal oxidation $[8,9]$ or by mechanical alloying $[10,11]$.

\section{Strengthening of the copper matrix}

\section{a. Internal oxidation}

During high-energy milling aluminum dissolved in the copper matrix, as more noble than copper, oxidizes first reacting with oxygen from the air and forming nanosized $\mathrm{Al}_{2} \mathrm{O}_{3}$ particles.

\section{b. Mechanical alloying}

Both nano- and micro-sized $\mathrm{Al}_{2} \mathrm{O}_{3}$ particles may be used as a strengthener during the process of mechanical alloying. High-energy milled powders are characterized by very fine, nano-scaled grain structure, which may be retained even during compaction and at temperatures near the melting point. This fine-grained structure contributes to copper matrix strengthening together with $\mathrm{Al}_{2} \mathrm{O}_{3}$ particles.

Three copper-based alloys, i.e. two composites reinforced with $\mathrm{Al}_{2} \mathrm{O}_{3}$ particles and fabricated through powder metallurgy $(\mathrm{P} / \mathrm{M})$ route and $\mathrm{Cu}-\mathrm{Cr}-\mathrm{Zr}$ alloy processed by standard melting and casting procedure were studied. The main objective was to investigate the effect of processing on microstructure, hardness, electrical conductivity and thermal stability of these materials during high temperature annealing.

\section{Experimental}

\section{Material and processing}

Processing parameters for production of samples used in experiments are shown in Table 1.

Table 1 Processing parameters.

\begin{tabular}{|c|c|c|}
\hline Material & Processing & Product \\
\hline $\mathrm{P} / \mathrm{M}$-internal oxidation & Prealloyed $\mathrm{Cu}-2.5 \mathrm{Al}$ powder & $\begin{array}{c}\mathrm{Cu}-4.7 \mathrm{Al}_{2} \mathrm{O}_{3} \\
\text { (after internal } \\
\text { oxidation) }\end{array}$ \\
\hline $\begin{array}{c}\mathrm{P} / \mathrm{M}-\text { mechanical } \\
\text { milling }\end{array}$ & Copper powder $+5 \mathrm{Al}_{2} \mathrm{O}_{3}$ \\
\hline $\begin{array}{c}\text { Vacuum melting and } \\
\text { casting }\end{array}$ & $\begin{array}{c}\text { Oxygen free high conductivity } \\
\text { copper }(\mathrm{OFHC})+(\mathrm{Cu}-10 \mathrm{Cr}+ \\
\text { Cu-30Zr) master alloys }\end{array}$ & $\mathrm{Cu}-0.4 \mathrm{Cr}-0.08 \mathrm{Zr}$ \\
\hline
\end{tabular}


Powders were separately milled in air for $5 \mathrm{~h}$ in the planetary ball mill. Following milling, powders were treated in hydrogen atmosphere at $400^{\circ} \mathrm{C}$ for $1 \mathrm{~h}$ in order to eliminate copper oxides formed at the surface during milling. Compaction executed by hot-pressing was carried out in an argon atmosphere at $800^{\circ} \mathrm{C}$ for $1 \mathrm{~h}$ under the pressure of $35 \mathrm{MPa}$. Milling in air of prealloyed copper powder promoted formation of $4.7 \mathrm{wt} \%$ of finely dispersed $\mathrm{Al}_{2} \mathrm{O}_{3}$ particles by internal oxidation.

Ingots of $\mathrm{Cu}-0.4 \mathrm{Cr}-0.08 \mathrm{Zr}$ alloy with $40 \mathrm{~mm}$ in diameter and $180 \mathrm{~mm}$ in height were produced by melting and casting in a laboratory vacuum furnace. Thermomechanical treatment (TMT) was executed in the following manner: hot rolling (to the predetermined diameter) at the temperature between 800 and $850^{\circ} \mathrm{C} \rightarrow$ solution annealing at $960^{\circ} \mathrm{C}$ for $1 \mathrm{~h} \rightarrow$ water quenching $\rightarrow$ cold rolling (degree of plastic deformation was $50 \%$ ) $\rightarrow$ aging (temperature of aging and time of aging were $425^{\circ} \mathrm{C}$ and $2 \mathrm{~h}$, respectively).

The shape and dimensions of samples are shown in Figure 2.

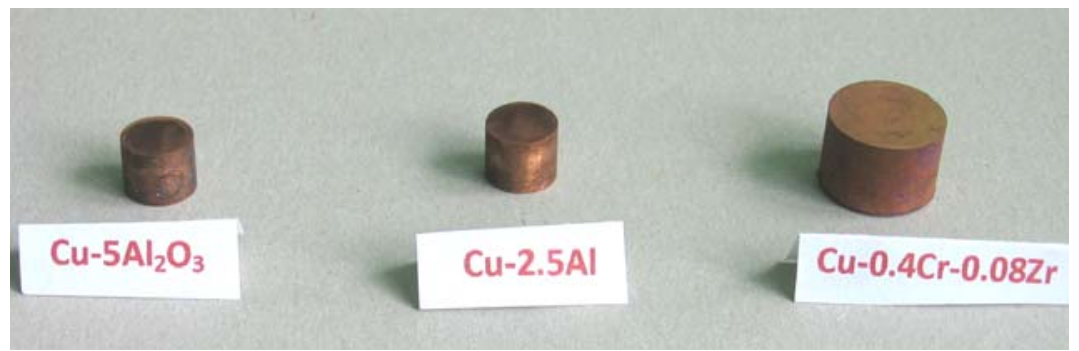

Figure 2 Samples obtained by $P / M$ and ingot metallurgy $D_{P M}=10 \mathrm{~m}, H_{P M}=10 \mathrm{~mm}$;

$$
D_{I N G}=15 \mathrm{~mm}, H_{I N G}=18 \mathrm{~mm} \text {. }
$$

\section{Thermal stability}

All samples were subjected to high temperature exposure in argon for $4 \mathrm{~h}$ in the range of temperatures from $300-950^{\circ} \mathrm{C}$.

\section{Methods of characterization}

The microstructure of samples was characterized by light microscope "Zeiss Axiovert 25" and scanning electron microscope (SEM) "JEOL JSM-6610LV" equipped with electron dispersive X-ray spectroscope (EDS). Samples for microstructural investigations were polished applying the standard procedure, whereas a mixture of $5 \mathrm{~g}$ $\mathrm{FeCl} 3$ and $50 \mathrm{ml} \mathrm{HCl}$ in $100 \mathrm{ml}$ distilled water was used for etching. The reinforcing of copper matrix was estimated by the microhardness measurements applying load of $50 \mathrm{~g}$. The density of samples was determined by the Archimedes method. The electrical conductivity, expressed in \% IACS (IACS $20{ }^{\circ} \mathrm{C}=0.5800 \mathrm{~m} \Omega-1 \mathrm{~cm}-1$ ) was measured at $60 \mathrm{kHz}$ on polished compacts using "Sigmatest 2.0 6.8." apparatus with electrode diameter of $14 \mathrm{~mm}$.

\section{Results and discussion} Table 2 .

Properties of investigated materials before thermal conductivity tests are given in 
Table 2 Designations and properties of samples before thermal stability tests.

\begin{tabular}{|c|c|c|c|c|c|c|}
\hline Designation & $\begin{array}{c}\text { Type of } \\
\text { process }\end{array}$ & Samples & $\begin{array}{c}\text { Density, } \\
\mathbf{g c m}^{-3}\end{array}$ & $\begin{array}{c}\text { Percent of } \\
\text { theoretical } \\
\text { density, } \\
\text { \% }\end{array}$ & $\begin{array}{c}\text { Microhardness } \\
\text { HV }_{\text {50g }}\end{array}$ & $\begin{array}{c}\text { Electrical } \\
\text { conductivity } \\
\text { (\%IACS) }\end{array}$ \\
\hline $\mathrm{Cu}-2.5 \mathrm{Al}$ & $\begin{array}{c}\text { Internal } \\
\text { oxidation }\end{array}$ & $\begin{array}{c}\text { Cylinder/ } \\
\text { compact }\end{array}$ & 8.02 & 94.79 & 250 & 67 \\
\hline $\mathrm{Cu}-5 \mathrm{Al}_{2} \mathrm{O}_{3}$ & $\begin{array}{c}\text { Mechanical } \\
\text { alloying }\end{array}$ & $\begin{array}{c}\text { Cylinder/ } \\
\text { compact }\end{array}$ & 7.92 & 93.84 & 155 & 87 \\
\hline $\begin{array}{c}\mathrm{Cu}-0.4 \mathrm{Cr}- \\
0.08 \mathrm{Zr}\end{array}$ & $\begin{array}{c}\text { Vacuum } \\
\text { metallurgy } \\
+ \text { TMT }\end{array}$ & $\begin{array}{c}\text { Cylinder/ } \\
\text { ingot }\end{array}$ & 8.93 & 100 & 150 & 90 \\
\hline
\end{tabular}

Values of Table 2 clearly demonstrate that the highest microhardness $-250 \mathrm{HV}_{50 \mathrm{~g}}$ was obtained in $\mathrm{Cu}-2.5 \mathrm{Al}$ composite processed by internal oxidation. On the other side, $\mathrm{Cu}-0.4 \mathrm{Cr}-0.08 \mathrm{Zr}$ alloy processed by vacuum melting exibited the highest electrical conductivity $-90 \%$ IACS.

\section{Microstructural examination}

The microstructure of a composite processed by internal oxidation from $5 \mathrm{~h}$ milled $\mathrm{Cu}-2.5 \mathrm{Al}$ powder is shown in Figure 3.
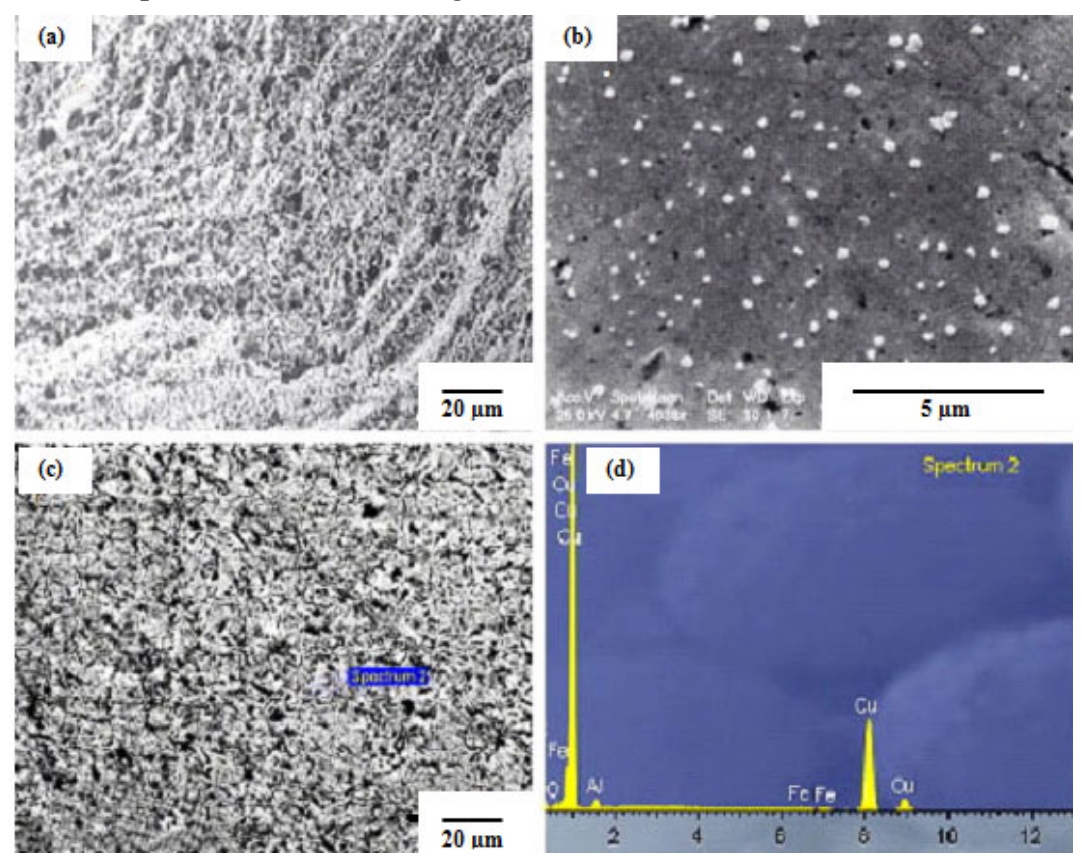

Figure 3 Microstructure of composite processed by internal oxidation from 5 h-milled

Cu-2.5Al powder. (a) Light microscope; (b) SEM BSE image; (c, d) SEM and EDS spectrum of a small particle, respectively. 
Small particles with the size less than $100 \mathrm{~nm}$ may be seen in copper matrix (Figure $3 b$ ). The presence of aluminium and oxygen in small particles was detected (Figure 3d) implying that their chemical composition is $\mathrm{Al}_{2} \mathrm{O}_{3}$.

The microstructure of composite obtained from $5 \mathrm{~h}$ milled $\mathrm{Cu}-5 \mathrm{Al}_{2} \mathrm{O}_{3}$ powder and processed by mechanical alloying is shown in Figure 4.

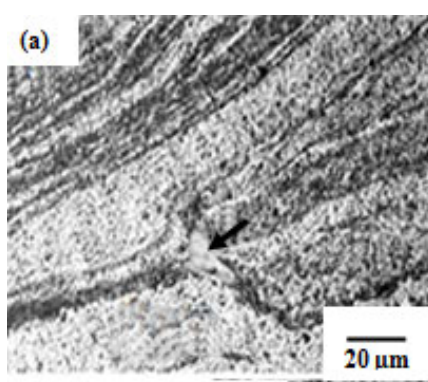

(d)

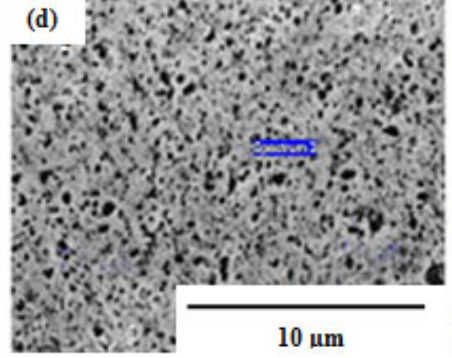

(b)

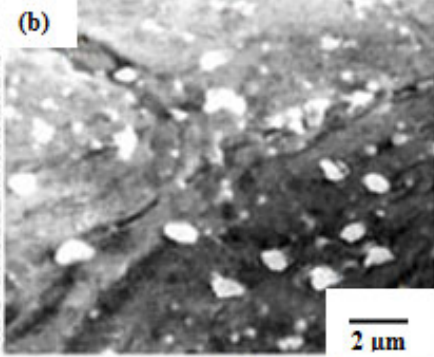

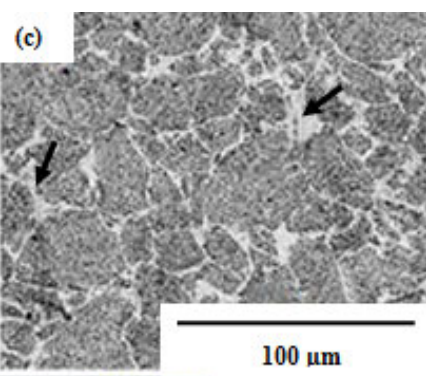

(e)

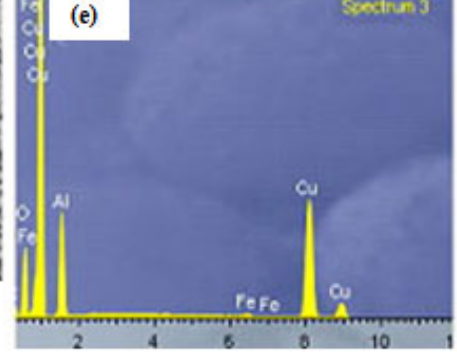

Figure 4 Microstructure of composite processed from 5 h-milled $\mathrm{Cu}$-5 $\mathrm{Al}_{2} \mathrm{O}_{3}$ powder. (a) Light microscope; $(b, c)$ SEM BSE image; $(d, e)$ SEM and EDS spectrum of a small particle, respectively. Arrows in Figure $4(a, c)$ denote the recrystallized regions.

Lamellar structure is preserved in compact after hot-pressing (Figure 4a). The size of $\mathrm{Al}_{2} \mathrm{O}_{3}$ particles was approximately $750 \mathrm{~nm}$ in diameter (Figure $4 \mathrm{~b}$ ). Recrystallization (Figure 4c) was more pronounced than in $\mathrm{Cu}-2.5 \mathrm{Al}$ compact indicating that coarse $\mathrm{Al}_{2} \mathrm{O}_{3}$ particles are less efficient in preventing grain growth than smaller particles.

Microstructure of $\mathrm{Cu}-0.4 \mathrm{Cr}-0.08 \mathrm{Zr}$ alloy processed by vacuum melding and casting and after TMT is shown in Figure 5.
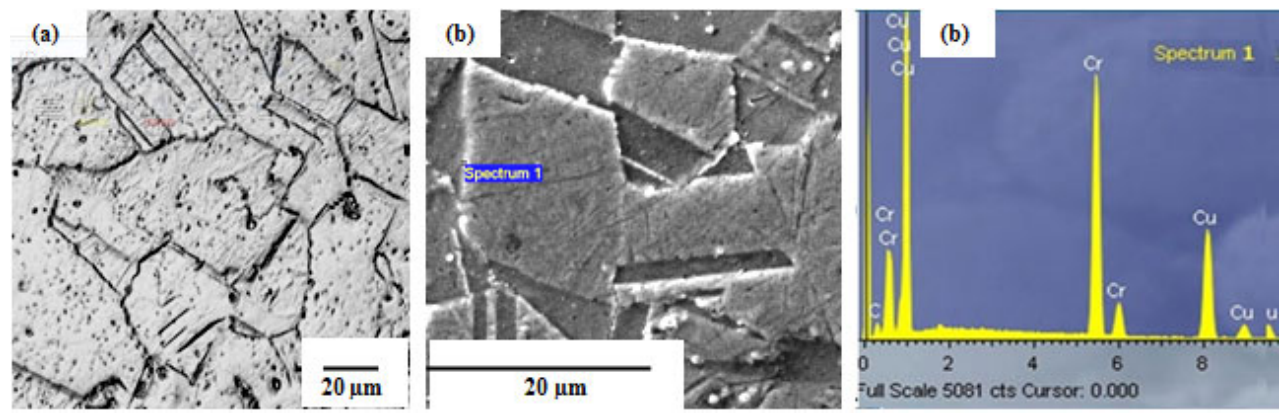

Figure 5 Microstructure of Cu-0.4Cr-0.08Zr alloy after TMT. (a) Light microscope; (b,c) SEM analysis: BSE image and EDS spectrum of a particle inside the grain, respectively. 
Supersaturated solid solution of $\mathrm{Cu}-\mathrm{Cr}-\mathrm{Zr}$ alloys is strengthened during aging with very fine $\mathrm{Cu}_{5} \mathrm{Zr}$ [12] precipitates. Globular and rod-like particles rich in chromium are actually a product of eutectic reaction during solidification and they do not play any role in strengthening.

\section{Thermal stability}

The effect of high temperature exposure in the range $300-950^{\circ} \mathrm{C}$ for $4 \mathrm{~h}$ on microhardness of composites and $\mathrm{Cu}-0.4 \mathrm{Cr}-0.08 \mathrm{Zr}$ alloy is presented in Figure 6.

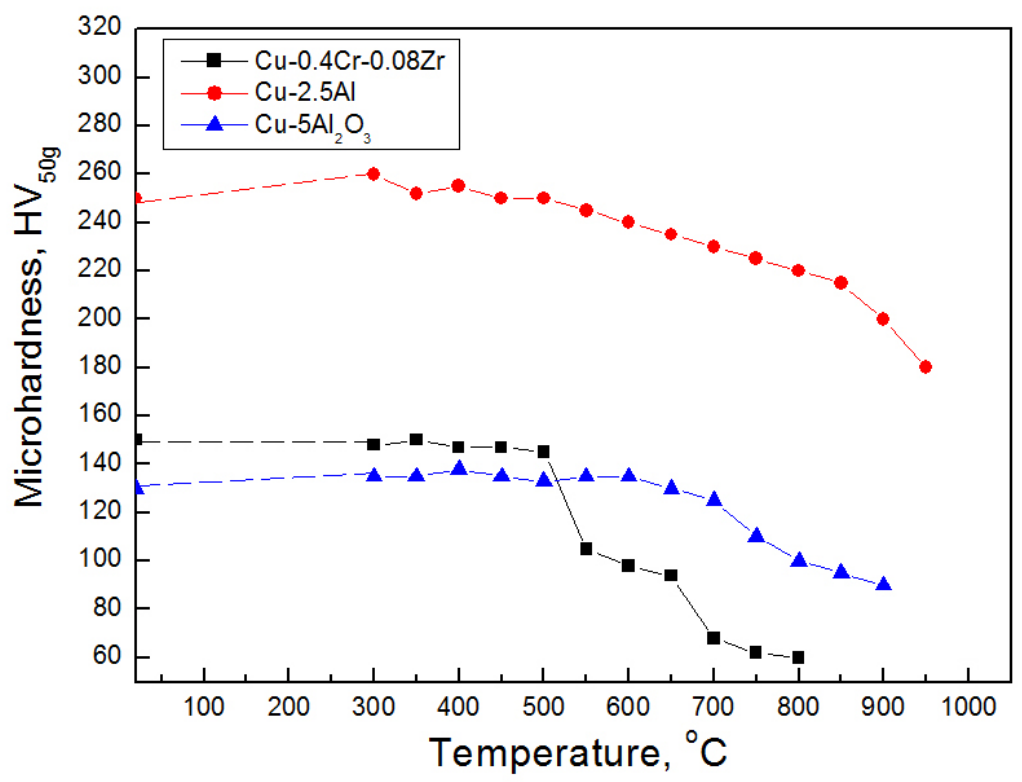

Figure 6 Microhardness as a function of high temperature exposure.

Composites behave much better than the alloy processed by the „classical” method. The highest level of microhardness shows $\mathrm{Cu}-2.5 \mathrm{Al}$ composite processed by internal oxidation.

According to the standard [13] thermal stability is determined by the highest temperature at which the hardness decreases for $15 \%$ in relation to the initial hardness. Values of $T_{s}$, corresponding to softening temperature, and obtained from diagrams in Figure 6 are given in Table 3. Actually, $T_{\mathrm{s}}$ determines the limit of applicability of a material at high temperatures

Table 3 Thermal stability $T_{s}$ as a function of processing.

\begin{tabular}{|c|c|c|}
\hline Material & Type of process & $\mathbf{T}_{\mathbf{s}}{ }^{\mathbf{0}} \mathbf{C}$ \\
\hline $\mathrm{Cu}-2.5 \mathrm{Al}$ & Internal oxidation & 925 \\
\hline $\mathrm{Cu}-5 \mathrm{Al}_{2} \mathrm{O}_{3}$ & Mechanical alloying & 680 \\
\hline $\mathrm{Cu}-0.4 \mathrm{Cr}-0.08 \mathrm{Zr}$ & Vacuum melting and casting & 525 \\
\hline
\end{tabular}


Highest microhardness is the consequence of the role of nano-particles and fine grained structure which also maintain high thermal stability of $\mathrm{Cu}-2.5 \mathrm{Al}$ composite. It may be assumed that nano-sized $\mathrm{Al}_{2} \mathrm{O}_{3}$ particles some of which are distributed at the grain boundaries and dislocations will slow down the grain growth in $\mathrm{Cu}-2.5 \mathrm{Al}$ composite [14]. Recrystallization is moved to temperatures even above $800^{\circ} \mathrm{C}$.

The lower microhardness (nearly two times) compared to $\mathrm{Cu}-2.5 \mathrm{Al}$ is the direct consequence of increase of grain size in $\mathrm{Cu}-5 \mathrm{Al}_{2} \mathrm{O}_{3}$ composite suggesting that the role of micro-sized commercial $\mathrm{Al}_{2} \mathrm{O}_{3}$ particles in obstructing grain growth is less efficient.

It is evident that $\mathrm{Cu}-0.4 \mathrm{Cr}-0.08 \mathrm{Zr}$ alloy could not survive this competition. Although fine $\mathrm{Cu}_{5} \mathrm{Zr}$ are formed at grain boundaries their ability to prevent dislocation motion and grain growth is less efficient than nano- and micro-sized $\mathrm{Al}_{2} \mathrm{O}_{3}$ particles. In this way recrystallization becomes active around $550^{\circ} \mathrm{C}$.

It is obvious that composites may be used at higher temperatures than „classically” processed alloy. Internal oxidation provides much higher $\mathrm{T}_{\mathrm{s}}$ compared to two other materials.

Optical microscopy (Figures 7-9) was applied to clarify phenomena occurring in the microstructure of samples subjected to high temperature annealing.
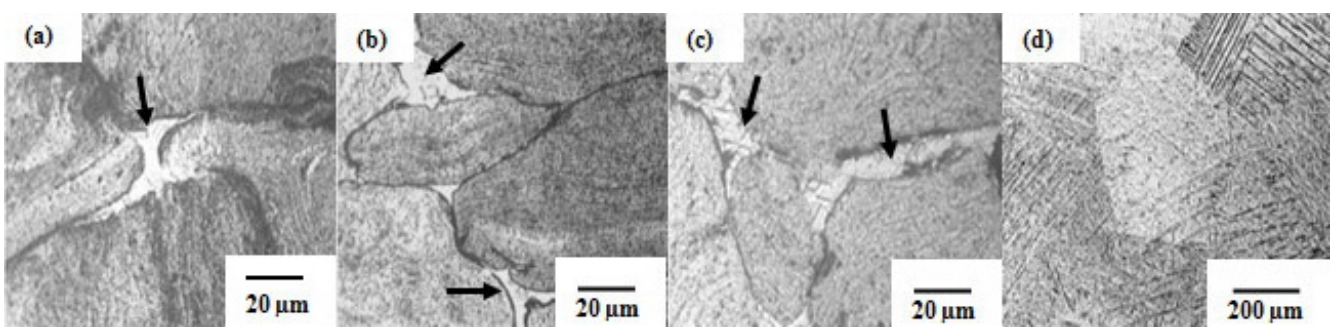

Figure 7 Light microscrope. Cu-2.5Al composite. Microstructure after high temperature exposure for $4 \mathrm{~h}$ at: (a) $850^{\circ} \mathrm{C}$; (b) $900^{\circ} \mathrm{C}$; (c and d) at $950^{\circ} \mathrm{C}$-minimum hardness. Arrows denote recrystallized regions.

Fully recrystallized microstructure (Figure 7d) leads to a significant microhardness drop.
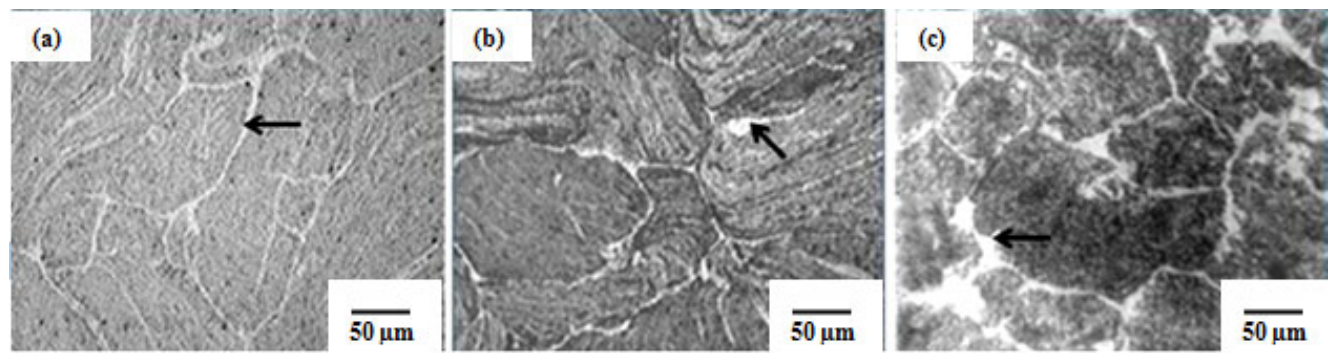

Figure 8 Light micrograph. $\mathrm{Cu}-5 \mathrm{Al}_{2} \mathrm{O}_{3}$ composite. Microstructure after high temperature exposure for 4 h at: (a) $70^{\circ} \mathrm{C}$; (b) $800^{\circ} \mathrm{C}$; $900^{\circ} \mathrm{C}$. Arrows denote recrystallized areas. 
Recrystallization is probably the main mechanism causing the decrease in microhardnes.
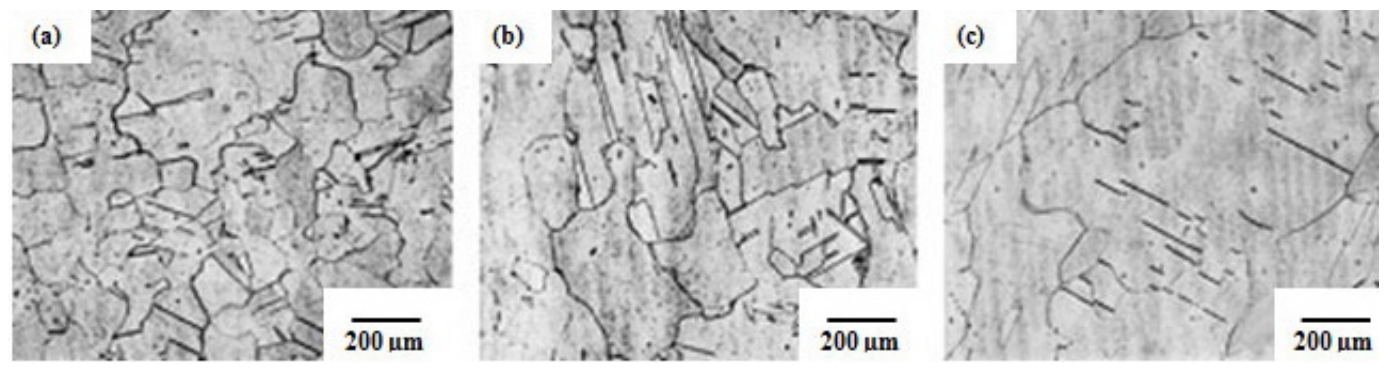

Figure 9 Light micrograph. Cu-0.4Cr-0.05Zr. Microstructure after high temperature exposure for $4 \mathrm{~h}$ at: (a) $400^{\circ} \mathrm{C}$; (b) $600^{\circ} \mathrm{C}$; (c) $700^{\circ} \mathrm{C}$.

Decrease in microhardness above $500^{\circ} \mathrm{C}$ is the consequence of recrystallization. The grain size was significantly increased.

\section{Electrical conductivity}

The change of electrical conductivity with temperature of different materials is given in Figure 10.

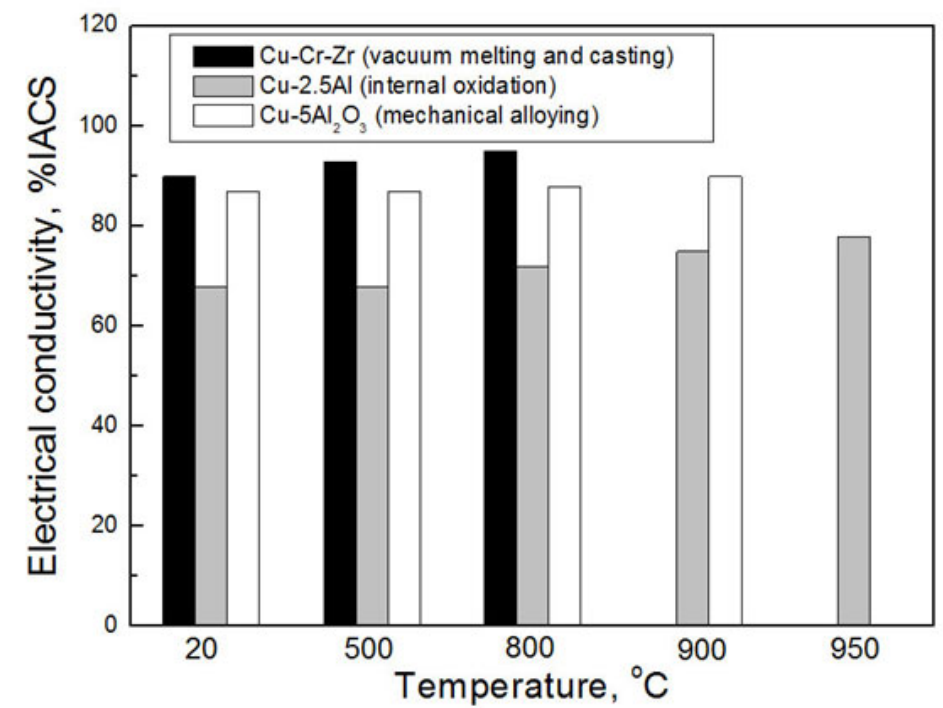

Figure 10 Dependence of electrical conductivity on temperature.

Compared to composite materials the values from Figure 10 explicitly indicate that $\mathrm{Cu}-0.4 \mathrm{Cr}-0.08 \mathrm{Zr}$ alloy possesses the highest electrical conductivity in the range from 20 to $800 \mathrm{oC}$, whereas the lowest conductivity shows composite $\mathrm{Cu}-2.5 \mathrm{Al}$ processed by internal oxidation. 


\section{Conclusions}

In conclusion values of microhardness and electrical conductivity at $T_{s}$ temperature are shown in Table 4.

Table 4 Values of microhardness and electrical conductivity at $T_{s}$ temperature of investigated materials.

\begin{tabular}{|c|c|c|c|}
\hline \multirow{2}{*}{ Material } & \multicolumn{3}{|c|}{ Properties } \\
\cline { 2 - 4 } & $\mathbf{T}_{\mathbf{s}} \mathbf{}^{\mathbf{0}} \mathbf{C}$ & $\begin{array}{c}\text { Microhardness, } \\
\mathbf{H V}_{\mathbf{5 0 g}}\end{array}$ & $\begin{array}{c}\text { El. conductivity, } \\
\text { \%IACS }\end{array}$ \\
\hline $\mathrm{Cu}-2.5 \mathrm{Al}$ & 925 & 200 & 77 \\
\hline $\mathrm{Cu}-5 \mathrm{Al}_{2} \mathrm{O}_{3}$ & 680 & 135 & 88 \\
\hline $\mathrm{Cu}-0.4 \mathrm{Cr}-0.08 \mathrm{Zr}$ & 525 & 108 & 93 \\
\hline
\end{tabular}

Although with somewhat lower electrical conductivity (probably due to inadequate density), $\mathrm{Cu}-2.5 \mathrm{Al}$ composite processed by internal oxidation exhibits superior properties enabling its application at much higher temperatures than materials processed by mechanical alloying or by vacuum melting and casting.

\section{Acknowledgement}

The authors are thankful for the financial support from the Ministry of Education and Science of the Republic of Serbia (national projects ON 172005, TR 35021 and TR 34028).

\section{References}

[1] A. Atrens, J. Nairn, H. Fernee, G. Skennerton, A. Olofinjana, Materials Forum, 21 (1997) 57.

[2] A. Chrysanthou, G. Erbaccio, J. Mat. Sci., 30 (1995) 6339-6344.

[3] Y.Z. Zhan, G.D. Zhang, Key Eng. Mat., 249 (2003) 227-232.

[4] K. Ichikawa, M. Achikita, Mat. Trans. JIM, 34 (1993) 718-724.

[5] http://www.863.org.cn/english/Forum/17.doc ,C. Jianyi, W. Mingpu, L.Z.W. Yanhui, China-EU Forum on Nanosized Technology, Beijing, P.R. China, Dec.2002.

[6] R.H Palma, A.O. Sepulveda, Mat. Sci. Forum, 416-418 (2003) 162.

[7] B. Tiang, P. Liu, K. Song, Y. Li, F. Ren, Mat. Sci. Eng., A 435-436 (2006) 705.

[8] Rajković, D. Božić, A. Devečerski, J. Serb. Chem.Soc., 72 (2007) 45-53.

[9] P.K. Jena, E.A. Brocchi, I.G. Solorzano, M.S. Motta, Mat. Sci. Eng., A 371 (2004) $72-78$.

[10] J.-H. Ahn, I.-H. Song, Y.-D. Hahn, Mat. Trans.JIM, 37 (1996) 733-737.

[11] A. Mukhtar, D.L. Zhang, C. Kong, P. Munroe, IOP Conference Series, Mat. Sci. Eng., 4 (2009) 012005.

[12] E. Kneller, Y. Khan, U. Gorres, Z. Metallkde, 77 (1986) 43.

[13] SRPS Standard, SRPS C.H.3, 074.

[14] Z. Szaraz, Z. Trojanova, M. Cabbibo, E. Evangelista, Mat. Sci. Eng.. A 462 (2007) 225-229. 